\title{
Impact of dietary fat quantity and quality on skeletal muscle fatty acid metabolism in subjects with the metabolic syndrome
}

Citation for published version (APA):

Jans, A., van Hees, A. M., Gjelstad, I. M., Sparks, L. M., Tierney, A. C., Riserus, U., Drevon, C. A., Schrauwen, P., Roche, H. M., \& Blaak, E. E. (2012). Impact of dietary fat quantity and quality on skeletal muscle fatty acid metabolism in subjects with the metabolic syndrome. Metabolism-Clinical and Experimental, 61(11), 1554-1565. https://doi.org/10.1016/j.metabol.2012.04.003

Document status and date:

Published: 01/01/2012

DOI:

10.1016/j.metabol.2012.04.003

Document Version:

Publisher's PDF, also known as Version of record

\section{Document license:}

Taverne

Please check the document version of this publication:

- A submitted manuscript is the version of the article upon submission and before peer-review. There can be important differences between the submitted version and the official published version of record.

People interested in the research are advised to contact the author for the final version of the publication, or visit the DOI to the publisher's website.

- The final author version and the galley proof are versions of the publication after peer review.

- The final published version features the final layout of the paper including the volume, issue and page numbers.

Link to publication

\footnotetext{
General rights rights.

- You may freely distribute the URL identifying the publication in the public portal. please follow below link for the End User Agreement:

www.umlib.nl/taverne-license

Take down policy

If you believe that this document breaches copyright please contact us at:

repository@maastrichtuniversity.nl

providing details and we will investigate your claim.
}

Copyright and moral rights for the publications made accessible in the public portal are retained by the authors and/or other copyright owners and it is a condition of accessing publications that users recognise and abide by the legal requirements associated with these

- Users may download and print one copy of any publication from the public portal for the purpose of private study or research.

- You may not further distribute the material or use it for any profit-making activity or commercial gain

If the publication is distributed under the terms of Article $25 \mathrm{fa}$ of the Dutch Copyright Act, indicated by the "Taverne" license above, 


\title{
Impact of dietary fat quantity and quality on skeletal muscle fatty acid metabolism in subjects with the metabolic syndrome
}

\author{
Anneke Jans ${ }^{a}$, Anneke M.J. van Hees $^{a}$, Ingrid M.F. Gjelstad ${ }^{b, c}$, Lauren M. Sparks ${ }^{a}$, \\ Audrey C. Tierney ${ }^{d}$, Ulf Risérus ${ }^{e}$, Christian A. Drevon ${ }^{b}$, Patrick Schrauwen ${ }^{a}$, \\ Helen M. Roche ${ }^{d}$, Ellen E. Blaak ${ }^{a, *}$ \\ a Department of Human Biology, NUTRIM School for Nutrition, Toxicology and Metabolism, Maastricht University Medical Centre+, \\ PO Box 616, 6200 MD Maastricht, the Netherlands \\ ${ }^{\mathrm{b}}$ Department of Nutrition, Institute of Basic Medical Sciences, Faculty of Medicine, University of Oslo, Oslo, Norway \\ c Department of Endocrinology, Oslo University Hospital, Oslo, Norway \\ ${ }^{\mathrm{d}}$ Nutrigenomics Research Group, UCD Conway Institute of Biomolecular and Biomedical Research, School of Public Health, \\ University College Dublin, Belfield, Dublin 4, Republic of Ireland \\ e Department of Public Health and Caring Sciences, Clinical Nutrition and Metabolism, Uppsala University, Uppsala, Sweden
}

\section{A R T I C L E I N F O}

Article history:

Received 26 August 2011

Accepted 2 April 2012

Keywords:

Insulin resistance

Gene expression

Skeletal muscle lipid fractions

\begin{abstract}
A B S T R A C T
Insulin resistance is characterized by disturbances in lipid metabolism in skeletal muscle. Our aim was to investigate whether gene expression and fatty acid (FA) profile of skeletal muscle lipids are affected by diets differing in fat quantity and quality in subjects with the metabolic syndrome (MetS) and varying degrees of insulin sensitivity. 84 subjects (age $57.3 \pm 0.9 \mathrm{y}, \mathrm{BMI} 30.9 \pm 0.4 \mathrm{~kg} / \mathrm{m}^{2}, 42 \mathrm{M} / 42 \mathrm{~F}$ ) were randomly assigned to one of four isoenergetic diets: high-SFA (HSFA); high-MUFA (HMUFA) or two low-fat, high-complex carbohydrate diets, supplemented with 1.24 g/day of long-chain n-3 PUFA (LFHCCn-3) or control oil (LFHCC) for 12 weeks. In a subgroup of men $(n=26)$, muscle TAG, DAG, FFA and phospholipid contents were determined including their fractional synthetic rate (FSR) and FA composition at fasting and $4 \mathrm{~h}$ after consumption of a high-fat mixed-meal, both preand post-intervention. Genes involved in lipogenesis were downregulated after HMUFA (mean fold change -1.3) and after LFHCCn-3 (fold change -1.7) in insulin resistant subjects $\left(<\right.$ median of $\left.\left(\mathrm{S}_{\mathrm{I}}\right)\right)$, whereas in insulin sensitive subjects ( $>$ median of insulin sensitivity) the
\end{abstract}

Abbreviations: Mets, Metabolic Syndrome; FA, Fatty Acid; HSFA, High Saturated Fatty Acid; HMUFA, High Monounsaturated Fatty Acid; LFHCC, Low Fat High Complexed Carbohydrate; TAG, Triacylglycerol; DAG, Diacylglycerol; FFA, Free fatty acids; FSR, Fractional Synthetic Rate; PUFA, Polyunsaturated Fatty Acid; LC, Long Chain; PPAR, Peroxisome Proliferator-Activated receptor; SREBP, Sterol Regulatory Element Binding Protein 1c; PGC1 $\alpha$, Peroxisome Proliferators-Activated Receptor Coactivator $1 \alpha ; \beta$ 2M, $\beta$-2-microglobulin; RPL13a, Ribosomal Protein L13a; LPL, Lipoprotein Lipase; ACC2, Acetyl-CoA Carboxylase 2; mCPT1b, muscle Carnitine Palmitoyltransferase 1b; ChREBP, Carbohydrate Responsive Element Binding Protein; NDUFB5, NADH Dehydrogenase (Ubiquinone) $1 \beta$ subcomplex; SDHB, Succinate Dehydrogenase complex B; HSL, Hormone Sensitive Lipase; ATGL, Adipose Triglyceride Lipase; CD36, Cluster of Differentiation 36; FAS, Fatty Acid Synthase; DGAT1, Acyl CoA:diacylglycerol acyltransferase; CGI58, Comparative Gene identification 58; NRF1, Nuclear Respiratory Factor 1; SIRT1, Sirtuin 1; RPLP0, Ribosomal Protein Large P0; PL, Phospholipids; HDL, High Density Lipoprotein; GLC, Gas Liquid Chromatography; SEM, Standard Error of the Mean; ANOVA, One-way analysis of variance; HOMA $\mathrm{IR}_{\mathrm{R}}$, Homeostasis Model Assessment for insulin resistance; BMI, Body Mass Index.

Clinical Trial Registration Number: NCT00429195 (ClinicalTrials.gov).

* Corresponding author. Tel.: +31 043 3881503; fax: +31 0433670976.

E-mail address: blaak@maastrichtuniversity.nl (E.E. Blaak). 
opposite effect was shown (fold change +1.6 for both diets). HMUFA diet tended to decrease FSR in TAG $(P=.055)$ and DAG $(P=.066)$, whereas the LFHCCn-3 diet reduced TAG content $(P=.032)$. In conclusion, HMUFA and LFHCCn-3 diets reduced the expression of the lipogenic genes in skeletal muscle of insulin resistant subjects, whilst HMUFA reduced the fractional synthesis rate of DAG and TAG and LFHCC n-3 the TAG content. Our data indicate that these diets may reduce muscle fat accumulation by affecting the balance between FA synthesis, storage and oxidation.

() 2012 Elsevier Inc. All rights reserved.

\section{Introduction}

The metabolic syndrome (MetS) is a cluster of factors enhancing the risk for development of type 2 diabetes and cardiovascular diseases [1]. Insulin resistance of skeletal muscle is fundamental to the metabolic dysregulation associated with obesity and physical inactivity, and contributes to the development of the MetS [2]. Potential mechanisms contributing to reduced insulin signaling and action in skeletal muscle include an increased supply of triacylglycerol (TAG) and free fatty acids (FFA) to 'nonadipose' tissues, such as skeletal muscle ('lipid overflow' hypothesis) [2], reduction in muscle mitochondrial oxidative capacity [3] and increased intramuscular lipid accumulation [4]. The accumulation of lipids, like diacylglycerol (DAG) and ceramides [4], may reduce insulin action in the skeletal muscle by interfering with insulin signaling and/or by inducing inflammatory pathways [4-6]. Also, changes in the FA composition of muscle lipids may play a role in the etiology of insulin resistance. It has been shown that endurance exercise training reduced total DAG content in skeletal muscle, as well as the saturation of the DAG fraction; these changes in intramuscular lipids were correlated with improved glucose tolerance [7]. Furthermore, the FA composition of membrane phospholipids may influence the action of insulin in the skeletal muscle and is correlated with insulin sensitivity [811]. Higher levels of polyunsaturated fatty acids (PUFA) in cell membranes of cultured muscle cells increase membrane fluidity [8], the number of insulin receptors [12], the affinity of insulin to the insulin receptor [13] and glucose membrane transport [14]. Dietary intervention, aimed at reducing the intake of saturated fat, may improve lipid metabolism and insulin action in the MetS, possibly via effects on skeletal muscle FA handling [15]. It is unclear whether saturated fat should be replaced by carbohydrates or unsaturated fat, and little information is available on the relation between dietary fat quantity and quality and skeletal muscle FA handling in vivo. PUFA may chronically stimulate adipocyte differentiation $[15,16]$, thereby increasing lipid storage in adipose tissue and reducing lipid overflow towards muscle. A diet enriched with n-3 PUFA may increase long-chain (LC) n-3 PUFA in muscle cell membranes, thereby enhancing insulin sensitivity [11]. In addition, there are indications from human muscle cell lines, as well as rodents, that saturated fatty acids (SFA) accumulate preferentially as DAG, thereby inhibiting insulin signaling; whereas unsaturated FA are more readily converted into TAG $[17,18]$. Moreover, replacing SFA by unsaturated FA may favor fat oxidation above storage [17]. A 3-day high-carbohydrate diet has been shown to induce changes in partitioning of FA in healthy subjects, leading to increased fat deposition in liver and muscle, which might be related to lower postprandial dietary FA oxidation and altered partitioning of FA to tissue esterification [19]. Regarding the possible differential mechanisms tuned by different FA, there are clearly defined intracellular pathways. PUFA may regulate gene transcription, acting as

480 men and women with the metabolic syndrome in 8 european centres

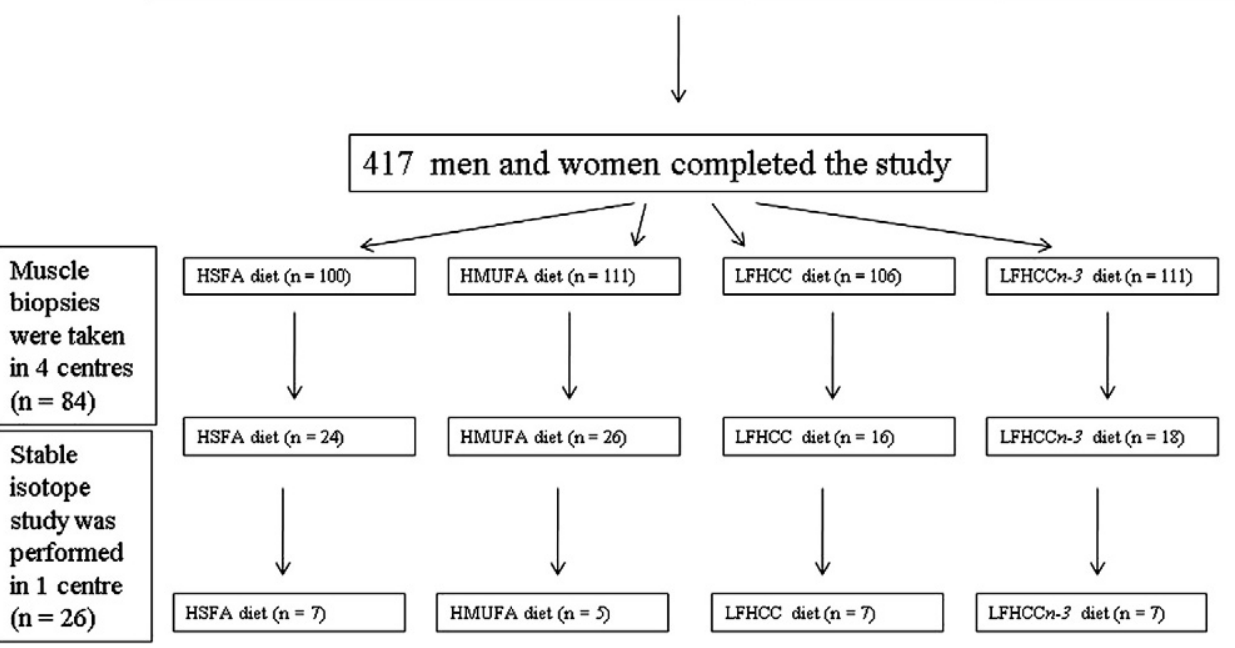

Fig. 1 - Flow chart of the study. Subjects were randomized to 4 diets. The stable isotope study in Maastricht, was performed in only male subjects. 
agonists of peroxisome proliferator-activated receptors (PPARs) (involved in FA catabolism) and down-regulate sterol regulatory element-binding protein 1c (SREBP1c) (lipogenic pathways) expression [20]; whereas SFA and MUFA have little effect on these processes [21]. Furthermore, it has been proposed that lipid infusion and energy excess promote reduced expression of genes encoding key enzymes in oxidative metabolism and mitochondrial function (regulated by the transcription factor PPAR gamma co-activator $1 \alpha$ $(P C G 1 \alpha)$ ) [22]. Recently, we validated an unique dual stable isotope tracer approach to study the contribution of dietary and endogenous FA to FA partitioning in detail. This technique makes it possible to study the contribution of dietary FA to skeletal muscle fat storage directly, which is very relevant since per os measurements will better reflect daily life conditions in humans than measurements under infusion conditions. The aim of the present study was to study the chronic effect (12 wk) of four isoenergetic diets differing in fat quality and quantity on skeletal muscle intracellular lipid partitioning and skeletal muscle lipid content and FA composition in subjects with the MetS.

\section{Methods}

The LIPGENE human dietary intervention study was a randomized, controlled trial, carried out at 8 centers across
Europe as part of the EU 6th Framework project LIPGENE (Contract no. FOOD-CT-2003-505944). In total, 486 volunteers with the MetS at the age of 35-70years and body mass index (BMI) $20-40 \mathrm{~kg} / \mathrm{m}^{2}$, were included and randomly assigned to receive one of four diets for a 12 -week period $[23,24]$. The present study was performed in a sub-cohort of the LIPGENE intervention study. All subjects were informed about the study and written informed consent was attained before study participation. The study protocol was approved by the local research ethics committees at each intervention center.

\subsection{Subjects and experimental design}

\subsubsection{Muscle gene expression}

In 4 out (Uppsala, Dublin, Oslo and Maastricht) of the 8 centers muscle biopsies were taken and all in a subgroup of subjects. A total of 84 muscle biopsies were available. The definition of the MetS was based on the NCEP ATP III report [25], with subjects meeting at least three out of five criteria as described previously [15]. In a subgroup of 26 men, skeletal muscle FA metabolism was studied in more detail by means of stable isotope tracers in one center, at Maastricht University (see Fig. 1). In the total LIPGENE study 486 subjects were included. We included in the present study all subjects from whom enough material was available. For this reason, the

\begin{tabular}{|c|c|c|c|}
\hline Gene & Forward primer & Probe & Reverse primer \\
\hline$\beta 2 \mathrm{M}$ & GGACTTCGAGCAAGAGATGG & & AGCACTGTGTTGGCGTACAG \\
\hline RPL13a & CCTGGAGGAGAAGAGGAAAGAGA & & TTGAGGACCTCTGTGTATTTGTCAA \\
\hline LPL & CATCTCTTGGGATACAGCCTTG & & GGGCTTCTGCATACTCAAAGT \\
\hline PPAR $\alpha$ & AAAAGCCTAAGGAAACCGTTCTG & & TATCGTCCGGGTGGTTGCT \\
\hline PGC1 $\alpha$ & CCAGGTCAAGATCAAGGTCTCCAG & & TTCGGTGCGTGCGGTGTC \\
\hline ACC2 & GCAAGAACGTGTGGGGTTACT & & TCGTAGTGGGCTTGCTGAAAA \\
\hline mCPT1b & CGGGACAGGGGTAAGTTCTG & & TCTCGCAGGTCTGCTTTTGTG \\
\hline SREBP1C & ACACAGCAACCAGAAACTCAAGC & & GCCGACACCAGATCCTTCAGAG \\
\hline SREBP2 & GCACCACTCCGCAGACGAG & & TGGACTTGAGGCTCAAGGACTTG \\
\hline ChREBP & GCCTCAAGGTGAGCAAAGCTA & & GCTGGCACAGGTTAATGGC \\
\hline NDUFB5 & GCTGCTCCTGTTCGACACA & & CTGCTAGTTCAGCTTGACCAAT \\
\hline SDHB & CCACAGCTCCCCGTATCAAG & & TCGGAAGGTCAAAGTAGAGTCAA \\
\hline PPARס & CCCTCACTGCTGGACCAAC & & GCGCTCACACTTCTCGTACT \\
\hline HSL & GCGGATCACACAGAACCTGGAC & & AGCAGGCGGCTTACCCTCAC \\
\hline ATGL & GTGTCAGACGGCGAGAATG & & TGGAGGGAGGGAGGGATG \\
\hline CD36 & AGTCACTGCGACATGATTAATGGT & CAGATGCAGCCTCATTTCCACСTTTTG & CTGCAATACCTGGCTTTTCTC \\
\hline FASN & TATGCTTCTTCGTGCAGCAGTT & AGCGCCTCCAGCACCCTGTTGT & GCTGCCACACGCTCСTCTAG \\
\hline SCD1 & TGGCATTCCAGAATGATGTCTATG & CGTGACCACCGTGCCCACCACA & GGAATTATGAGGATCAGCATGTGT \\
\hline DGAT1 & CGTGAGCTACCCGGACAATC & ACCTACCGCGATCTCTACTACTTCCTCTTCGC & AAAGTTGAGCTCGTAGCACAAGG \\
\hline CGI58 & GGAGAGAGGTCAGGATGGCTAA & СTCСССACATGGTGCССТACGTCTATATC & AACATCTTCTCTTCAGCTTCTTTAAGG \\
\hline NRF1 & CGTTGCCCAAGTGAATTATTCTG & TTGTTCCACCTCTCCATCAGCCA & CCCTGTAACGTGGCCCAAT \\
\hline SIRT1 & AGAGCCTCACATGCAAGCTCTAG & ACTCCAAGGCCACGGATAGGTCCATATACTT & GCCAATCATAAGATGTTGCTGAAC \\
\hline RPLPO & CCATTCTATCATCAACGGGTACAA & TCTCCACAGACAAGGCCAGGACTCG & AGCAAGTGGGAAGGTGTAATCC \\
\hline
\end{tabular}

$\beta 2 \mathrm{M}, \beta$-2-microglobulin; RPL13a, ribosomal protein L13a; LPL, lipoprotein lipase; PPAR $\alpha$, peroxisome proliferator-activated receptor $\alpha$; PGC1 $\alpha$, peroxisome proliferators-activated receptor coactivator $1 \alpha$; ACC2, acetyl-CoA carboxylase 2; mCPT1b, muscle carnitine palmitoyltransferase 1b; SREBP1c, sterol regulatory element binding protein 1c; SREBP2, sterol regulatory element binding protein 2; ChREBP, carbohydrate responsive element binding protein; NDUFB5, NADH dehydrogenase (ubiquinone) $1 \beta$ subcomplex; SDHB, succinate dehydrogenase complex B; PPAR $\delta$, peroxisome proliferator-activated receptor $\delta$; HSL, hormone sensitive lipase; ATGL, adipose triglyceride lipase; CD36, cluster of differentiation 36; FASN, fatty acid synthase; SCD1, stearoyl-CoA desaturase 1; DGAT1, acyl CoA:diacylglycerol acyltransferase; CGI58, comparative gene identification 58; NRF1, nuclear respiratory factor 1; SIRT1, sirtuin 1; RPLP0, ribosomal protein, large, P0. 
number of subjects was not similar in the different dietary groups.

Pre- and post-intervention, subjects came to the center after an overnight fast on two different occasions. In one day, the subjects completed anthropometric measurements, donated a fasting blood sample and completed an insulinmodified intravenous glucose tolerance test to measure insulin sensitivity as described previously [26,27]. Insulin sensitivity was the primary end point of the LIPGENE human dietary intervention study. On a separate day, after an overnight fast, a biopsy was taken from the vastus lateralis muscle under local anesthesia of the skin and fascia using the Bergström method with suction [28]. Biopsies were cleaned from any visible fat and blood, immediately frozen in isopentane at its melting point or RNA later, and stored at $-80^{\circ} \mathrm{C}$ until analysis.

\subsubsection{Muscle lipid metabolism}

In a sub-cohort of 26 men, a postprandial stable isotope study was performed pre- and post intervention in one center (Maastricht University) [15]. At time point zero (0 min) subjects consumed a standardized high-fat mixed-meal containing $200 \mathrm{mg}$ [U- ${ }^{13} \mathrm{C}$ ]-palmitate $(98 \%$ enrichment; Cambridge Isotope Laboratories). The high-fat mixed-meal was a liquid test meal providing $2.6 \mathrm{MJ}$, including 61\% energy (E\%) fat $(35.5 \mathrm{E} \%$ SFA, $18.8 \mathrm{E} \%$ MUFA and 1.7E\% PUFA), 33E\% carbohydrates and $6.3 \mathrm{E} \%$ protein.

Biopsies from skeletal muscle were taken at fasting before the experiment and at the end of the postprandial measurement period (240 min) to determine intramuscular TAG, DAG, FFA, and phospholipids (PL) content, their degree of saturation, as well as the fractional synthetic rate (FSR) of TAG, DAG, and PL (see skeletal muscle lipid analyses).

\subsection{Dietary intervention}

Subjects were randomly assigned to one of four iso-energetic intervention diets:

(1) High-fat (38E\%) SFA-rich diet (16E\% SFA, 12E\% monounsaturated fatty acids (MUFA), 6E\% PUFA) (HSFA)

(2) High-fat (38E\%) MUFA-rich diet (8E\% SFA, 20E\% MUFA, 6E\% PUFA) (HMUFA)

(3) Low-fat (28E\%), high-complex carbohydrate diet (8E\% SFA, 11E\% MUFA, 6E\% PUFA), with a control capsule (1 g per day) (LFHCC)

(4) Low-fat (28E\%), high-complex carbohydrate diet (8E\% SFA, 11E\% MUFA, 6E\% PUFA), with a long-chain $n-3$ PUFA supplement (1.24 g per day of eicosapentaenoic and docosahexaenoic acid, ratio 1.4:1) (LFHCCn-3)

The HSFA diet functioned as the control per reference diet, to reflect the fat content and composition of the Northern European diet. The intervention diets were specifically designed to reduce dietary SFA by replacement with MUFA or as part of an LFHCC diet, while keeping dietary energy and n-6 PUFA constant [24].

A range of fat-modified food products were provided to subjects with specific dietetic counseling, as described previously [15]. A food exchange model was developed, and carbohydrate-fat exchanges were used to ensure that all diets were isoenergetic. A detailed description of the food exchange model and assessment of compliance is published elsewhere [23]. Loders-Croklaan (Wormerveer, the Netherlands) supplied the study capsules used in diet LFHCC and LFHCCn-3. All subjects completed 3-day weighed food record at baseline, week 6 , and week 12, and center-specific dietary

Table 2 - Subject characteristics before and after dietary intervention.

\begin{tabular}{|c|c|c|c|c|c|c|c|c|}
\hline & \multicolumn{2}{|c|}{ HSFA $(n=24)$} & \multicolumn{2}{|c|}{ HMUFA $(n=26)$} & \multicolumn{2}{|c|}{ LFHCC $(n=16)$} & \multicolumn{2}{|c|}{ LFHCC $n-3(n=18)$} \\
\hline & Pre & Post & Pre & Post & Pre & Post & Pre & Post \\
\hline Men / Women & $12 / 12$ & & $13 / 13$ & & $8 / 8$ & & $9 / 9$ & \\
\hline Age (years) & $55.9 \pm 1.7$ & & $58.0 \pm 1.5$ & & $57.1 \pm 2.0$ & & $58.2 \pm 2.4$ & \\
\hline Height $(\mathrm{m})$ & $1.70 \pm 0.02$ & & $1.70 \pm 0.02$ & & $1.71 \pm 0.02$ & & $1.72 \pm 0.02$ & \\
\hline Body weight (kg) & $87.3 \pm 3.0$ & $87.1 \pm 3.1$ & $92.5 \pm 3.0$ & $92.4 \pm 2.9$ & $91.3 \pm 2.90$ & $90.1 \pm 2.7$ & $90.8 \pm 3.4$ & $90.1 \pm 3.6$ \\
\hline BMI $\left(\mathrm{kg} / \mathrm{m}^{2}\right)$ & $29.9 \pm 0.8$ & $29.8 \pm 0.8$ & $31.8 \pm 0.8$ & $31.8 \pm 0.8$ & $30.9 \pm 0.8$ & $30.6 \pm 0.8$ & $30.7 \pm 0.8$ & $30.4 \pm 1.0$ \\
\hline Waist (cm) & $103 \pm 2$ & $101 \pm 2$ & $105 \pm 2$ & $104 \pm 2$ & $105 \pm 2$ & $104 \pm 2$ & $104 \pm 2$ & $102 \pm 2$ \\
\hline WHR & $0.96 \pm 0.02$ & $0.96 \pm 0.02$ & $0.96 \pm 0.02$ & $0.95 \pm 0.02$ & $0.98 \pm 0.02$ & $0.98 \pm 0.02$ & $0.96 \pm 0.02$ & $0.96 \pm 0.03$ \\
\hline Systolic BP (mm Hg) & $138 \pm 3$ & $135 \pm 3$ & $137 \pm 3$ & $137 \pm 4$ & $145 \pm 4$ & $139 \pm 4$ & $134 \pm 3$ & $129 \pm 2$ \\
\hline Diastolic BP $(\mathrm{mm} \mathrm{Hg})^{a}$ & $86 \pm 2$ & $83 \pm 2$ & $86 \pm 2$ & $83 \pm 2$ & $91 \pm 2^{b}$ & $87 \pm 2$ & $82 \pm 2$ & $80 \pm 1$ \\
\hline Insulin sensitivity $\left(\mathrm{mU} / \mathrm{L}^{-1} \cdot \mathrm{min}^{-1} \cdot 10^{-4}\right)$ & $3.47 \pm 0.73$ & $3.25 \pm 0.41$ & $3.04 \pm 0.28$ & $2.69 \pm 0.30$ & $3.02 \pm 0.66$ & $3.21 \pm 0.43$ & $2.71 \pm 0.30$ & $2.99 \pm 0.31$ \\
\hline $\mathrm{HOMA}_{\mathrm{IR}}$ & $2.18 \pm 0.27$ & $2.40 \pm 0.37$ & $2.26 \pm 0.21$ & $2.27 \pm 0.30$ & $2.88 \pm 0.57$ & $2.70 \pm 0.70$ & $2.20 \pm 0.45$ & $2.03 \pm 0.26$ \\
\hline Glucose (mmol/L) & $5.79 \pm 0.14$ & $5.77 \pm 0.18$ & $6.02 \pm 0.15$ & $6.13 \pm 0.17$ & $6.16 \pm 0.24$ & $5.64 \pm 0.24$ & $6.20 \pm 0.16$ & $6.22 \pm 0.17$ \\
\hline Triglycerides (mmol/L) & $1.95 \pm 0.11$ & $1.77 \pm 0.09$ & $1.73 \pm 0.07$ & $1.68 \pm 0.08$ & $1.74 \pm 0.08$ & $1.75 \pm 0.09$ & $1.73 \pm 0.09$ & $1.56 \pm 0.06$ \\
\hline Total cholesterol $(\mathrm{mmol} / \mathrm{L})$ & $5.35 \pm 0.09$ & $5.35 \pm 0.09$ & $5.21 \pm 0.09$ & $5.12 \pm 0.10$ & $5.24 \pm 0.10$ & $5.13 \pm 0.10$ & $5.43 \pm 0.10$ & $5.17 \pm 0.11$ \\
\hline HDL-cholesterol (mmol/L) & $1.05 \pm 0.02$ & $1.12 \pm 0.03$ & $1.09 \pm 0.03$ & $1.14 \pm 0.03$ & $1.10 \pm 0.03$ & $1.09 \pm 0.03$ & $1.12 \pm 0.03$ & $1.11 \pm 0.03$ \\
\hline LDL-cholesterol (mmol/L) & $3.18 \pm 0.10$ & $3.16 \pm 0.09$ & $3.09 \pm 0.09$ & $3.00 \pm 0.09$ & $3.19 \pm 0.10$ & $3.11 \pm 0.11$ & $3.38 \pm 0.11$ & $3.15 \pm 0.11$ \\
\hline
\end{tabular}

Abbreviations: BMI, body mass index; WHR, waist-to-hip ratio; BP, blood pressure; HDL, high-density lipoprotein; HSFA, high-fat saturated fatty acid; HMUFA, high-fat monounsaturated fatty acid; LFHCC, low-fat high complex carbohydrate.

Values are means \pm SEM. No effects of dietary intervention, repeated measures ANOVA.

${ }^{a} \mathrm{P}<.05$ for the differences between groups pre-intervention, one-way ANOVA.

b $P=.040$, post hoc comparison to HMUFA. 
analysis programs were used to analyze the food diaries. Subjects should remain weight stable within the range of $2 \mathrm{~kg}$ during the intervention period, and were asked to maintain their normal pattern of physical activity, alcohol consumption and smoking.

\subsection{Biochemical analyses}

Blood for lipid analyses was collected in potassium EDTA vacutainer tubes. Glucose samples were collected in fluoride oxalate vacutainers, and insulin samples in serum tubes. All plasma samples were centrifuged immediately $\left(10 \mathrm{~min}, 4^{\circ} \mathrm{C}\right.$, $1500 \mathrm{~g}$ ), whereas serum samples were allowed to clot for $30 \mathrm{~min}$ at room temperature before centrifugation. Samples were then aliquoted and stored $\left(-80^{\circ} \mathrm{C}\right)$ until further analysis. Serum insulin concentrations were determined by solid phase, two-side fluoro-immunometric assays (AutoDELFIA Insulin kit, Wallac Oy, Turku, Finland) using a 1235 AutoDELFIA automatic immunoassay system. Plasma TAG, glucose and HDL-cholesterol were determined with an ILab 600 clinical chemical analyzer (Instrumentation Laboratory, Warrington, UK) using enzymatic colorimetric kits. Minimum detection limit and CV for plasma TAG, glucose and HDLcholesterol were $0.02 \mathrm{mmol} / \mathrm{L}$ and $0.9 \%, 0.1 \mathrm{mmol} / \mathrm{L}$ and $0.8 \%$ and $0.05 \mathrm{mmol} / \mathrm{L}$ and $0.5 \%$, respectively. HDL-cholesterol was monitored by an HDL-cholesterol kit (Instrumentation Laboratory, Warrington, UK).

\subsection{Skeletal muscle lipid analyses}

Skeletal muscle biopsies were lyophilized and dissected free of extra-myocellular fat, blood, and connective tissue. Total lipids were extracted from 10-20 mg muscle sample using chloroform-methanol (2:1 vol/vol) and internal standards, and thereafter evaporated under nitrogen at $37^{\circ} \mathrm{C}$. The extracted lipids were separated into FFA, DAG, TAG, and PL by thin-layer chromatography and transferred into tubes for methylation. The TAG and DAG fractions were methylated by adding $1 \mathrm{~mL}$ of toluene-methanol-(BF3-methanol $14 \%)(20 \%-55 \%-25 \% \mathrm{vol} / \mathrm{vol})$ and incubated in capped tubes for $30 \mathrm{~min}$ at $100^{\circ} \mathrm{C}$. The PL fraction was methylated by adding $1 \mathrm{~mL}$ of (BF3-methanol 14\%) and incubation in capped tubes for $90 \mathrm{~min}$ at $100{ }^{\circ} \mathrm{C}$. The FFA fraction was methylated by adding $1 \mathrm{~mL}$ of methanol-(BF3-methanol 14\%) (50\%-50\% vol/vol) and incubation in capped tubes at room temperature for $15 \mathrm{~min}$. After incubation, $2 \mathrm{~mL}$ pentane was added to the samples, vortexed, and centrifuged $(1000 \mathrm{~g}$, $5 \mathrm{~min}, 20^{\circ} \mathrm{C}$ ), followed by isolation of the pentane extracts (upper phase) and evaporation under nitrogen at $30^{\circ} \mathrm{C}$ Finally, the residues were dissolved in isooctane and concentrations of fatty acids in the fractions were determined using an analytical gas liquid chromatograph (GLC). Stable isotope enrichment of the lipid fractions was determined by measuring the ${ }^{13} \mathrm{C}$-to- ${ }^{12} \mathrm{C}$ ratio on a GLCIRMS (Finnigan MAT-252).

\subsection{Skeletal muscle mRNA and DNA isolation}

RNA was isolated from approximately $25 \mathrm{mg}$ of muscle tissue. The tissues were homogenized in $1 \mathrm{~mL}$ Trizol for
RNA stabilization and subsequent RNA isolation according to a standardized protocol described by manufacturer. RNA was then purified using the RNeasy mini kit (Qiagen Benelux BV, Venlo, the Netherlands) followed by dissolving RNA in RNase and DNase free water. RNA was quantified
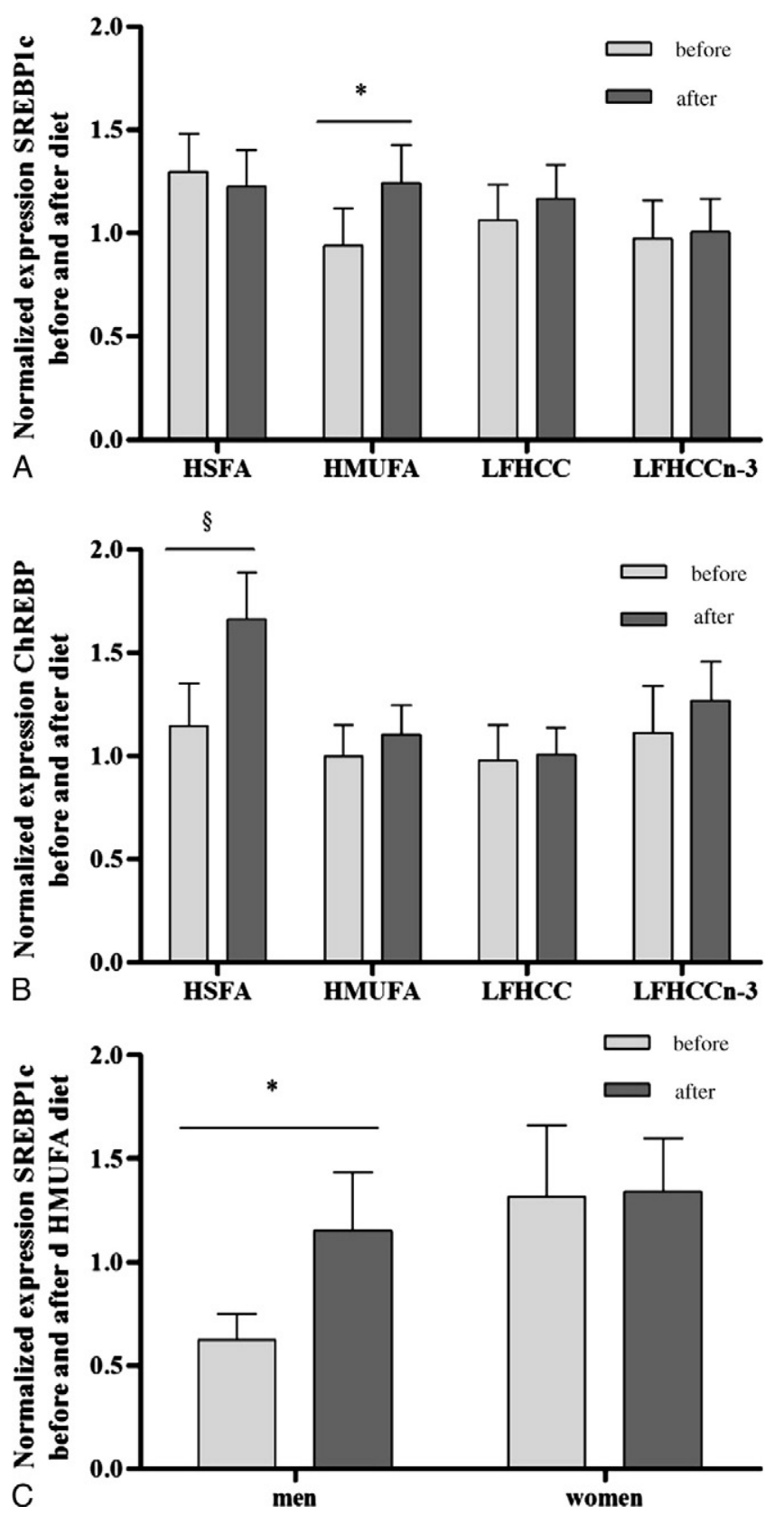

Fig. 2 - Normalized mRNA levels before and after dietary intervention (mean \pm SEM). SREBP1c (A), ChREBP (B) and SREBP1c after HMUFA diet for men $(n=13)$ and women $(n=13)$ (C). The overall difference for SREBP1c was $P=.048$, with a post-hoc difference after the HMUFA diet $(P=.070)$. For ChREBP the overall difference was $P=.007$, with a tendency for increase after the HSFA diet. Paired $t$ test showed an increase for SREBP1C in men after the HMUFA diet $(P=.020)$. Significant post-hoc differences within the diets are indicated with ${ }^{*}$. ${ }^{*} \mathrm{P}<.05$. 
and checked for purity on the NanoDrop 1000 (NanoDrop Technologies, Wilmington, DE), and considered suitable for further processing at ratios between $260 / 280$ and 260/230 of >1.7. RNA integrity was evaluated using the BioAnalyzer (Agilent, Palo Alto, CA) and considered to be intact with an RNA integrity number $>7.0$. Total DNA was isolated from $5 \mathrm{mg}$ of each muscle section using QIAqmp DNQ Micro Kit (Qiagen).

\subsection{Real-time qRT-PCR for RNA}

Both SYBR Green and Taqman were used for quantification of mRNA expression levels. For expression of the genes in the upper half of Table 1, isolated RNA was reversely transcribed using the iScript cDNA synthesis Kit. The qPCRs were performed in a volume of $25 \mu \mathrm{L}$ containing $12.5 \mathrm{ng}$ cDNA, $1 \times$ IQ SYBR Green Supermix and $400 \mathrm{nmol} / \mathrm{L}$ of genespecific forward and reverse primers (Table 1). cDNA was amplified using a two-step program (40 cycles of $10 \mathrm{~s}$ at $95^{\circ} \mathrm{C}$ and $45 \mathrm{~s}$ at $60^{\circ} \mathrm{C}$ ) with a MyiQ system (Bio-Rad Laboratiories, Veenendaal, the Netherlands). Gene expression levels were expressed relative to geometric mean of two internal reference genes, i.e. ribosomal protein L13a (RPL13a) and $\beta$-2-microglobulin. For expression of genes in the lower half of Table 1, all primers and probes were designed using Primer Express version 2.1 (Applied Biosystems, Roche, Branchburg, NJ). qRT-PCRs [29] were performed as one-step reactions in ABI PRISM 7900 (Applied Biosystems, Branchburg, NJ) using the following conditions: one cycle of $48^{\circ} \mathrm{C}$ for $30 \mathrm{~min}$, then $95^{\circ} \mathrm{C}$ for $10 \mathrm{~min}$, followed by 40 cycles at $95^{\circ} \mathrm{C}$ for $15 \mathrm{~s}$ and $60^{\circ} \mathrm{C}$ for $1 \mathrm{~min}$. For all assays performed using Taqman primers and probe, the ribosomal phosphoprotein large PO gene (RPLPO) was used as internal control. Dividing the target genes by the internal control RPLPO gene normalized all expression data. The internal control gene was tested for inter-individual variability with a coefficient of variance to ensure precision in the measurements.

\subsection{Mitochondrial DNA content}

Quantification of mitochondrial content was performed as previously described using mtDNA copy number [30]. The sequences for the primer/probe sets used in the Taqman analysis of mtDNA content for NADH dehydrogenase subunit 1 (mitochondrial genome (ND1)) and of nuclear DNA for lipoprotein lipase (LPL), were designed using Primer express version 2.1 and can be e-mailed on request.

\subsection{Calculations}

Insulin sensitivity was determined using the MINMOD Millennium program (version 6.02; R Bergman, Los Angeles, CA) [27]. The homeostasis model assessment for insulin resistance $\left(\mathrm{HOMA}_{\mathrm{IR}}\right)$ was calculated according to Matthews et al [31]. The fractional synthetic rate (FSR) is expressed as the amount of dietary FA incorporated into the muscle lipid fractions per gram of dry muscle tissue per hour. The enrichment (determined by measuring the ${ }^{13} \mathrm{C}$-to- ${ }^{12} \mathrm{C}$ ratio) of the skeletal muscle FFA pool at $4 \mathrm{~h}$ after meal consumption was used to represent the precursor pool from which the TAG, DAG and PL pool was synthesized.

$\operatorname{TAGFSR}(\% / \mathrm{h})=\frac{\mathrm{E}_{\mathrm{TAGpalm}}\left(\mathrm{t}_{1}\right)-\mathrm{E}_{\mathrm{TAGpalm}}\left(\mathrm{t}_{0}\right)}{\mathrm{E}_{\mathrm{FFApalm}}\left(\mathrm{t}_{1}\right)} * \frac{1}{4} * 100$

Where $E_{T A G}$ palm $\left(t_{1}\right)$ is the enrichment of palmitate in the TAG pool after $4 \mathrm{~h}$ of ingestion and $E_{\text {TAG palm }}\left(t_{0}\right)$ is the background enrichment in the muscle TAG pool. $E_{F F A}$ palm $\left(t_{1}\right)$ is the enrichment of palmitate in the FFA pool after $4 \mathrm{~h}$ of ingestion. The content of individual FA in the TAG, DAG, FFA and PL pool extracted from the muscle was expressed as a percentage of the total FA identified. Several indices (the sum of SFA, the sum of MUFA, the sum of PUFA $(n-6$ and $n-3)$ ) were derived.

\subsection{Statistical methods}

Statistical analyses were performed using SPSS 16.0 for Macintosh (SPSS, Chicago, IL). All data are presented as means \pm standard error of the means (SEM). The data were normally distributed as tested with the Kolmogorov-Smirnov test. One-way analysis of variance (ANOVA) was used to test for differences between dietary intervention groups pre-intervention. Repeated-measures ANOVA was applied to test for differences in changes between groups pre- and post-intervention, with time as within-subjects factor and diet and center as between-subjects factors. Corrections for gender, insulin sensitivity and baseline differences were performed in the repeated-measures ANOVA analysis. Posthoc testing within diets was performed with paired sampled $t$ test. One-way ANOVA was used to test differences in change in gene expression between insulin resistant and insulin sensitive subjects. Statistical significance was set at $P<.05$.

\section{Results}

In total, 84 subjects with the MetS completed pre- and postintervention measurements (HSFA, $n=24$; HMUFA, $n=26$; LFHCC, $n=16$ and LFHCC $n-3, n=18)$. Subject characteristics were comparable between all the groups pre-intervention, except for diastolic blood pressure, which was higher in the LFHCC group than in the HMUFA group (Table 2). By definition, subjects primarily had a large waist circumference, elevated blood pressure and low plasma HDL-cholesterol concentrations, whereas mean fasting plasma glucose and TAG concentrations were only slightly elevated. The dietary intervention did not cause significant changes in the characteristics of the MetS and did not change insulin sensitivity and insulin resistance $\left(\mathrm{HOMA}_{\mathrm{IR}}\right)$ in our sub-cohort of the LIPGENE study (Table 2).

\subsection{Muscle gene expression}

\subsubsection{Changes after dietary intervention}

Skeletal muscle SREBP1c and ChREBP mRNA expression showed significant diet*time interactions $(P=.048$ and $P=.007$ ), respectively (Fig. $2 \mathrm{~A}$ and $\mathrm{B}$ ). Post-hoc comparisons within the diets showed that SREBP1c mRNA only tended 
to increase after the HMUFA diet $(P=.070$, Fig. $2 A)$, whereas the other diets did not induce any change. A genderanalysis showed that this increased SREBP-1c expression was only seen in men $(P=.020$, Fig. $2 \mathrm{C})$. No interactions between gender and diet-induced changes in gene expression were observed for the other genes. Post-hoc testing
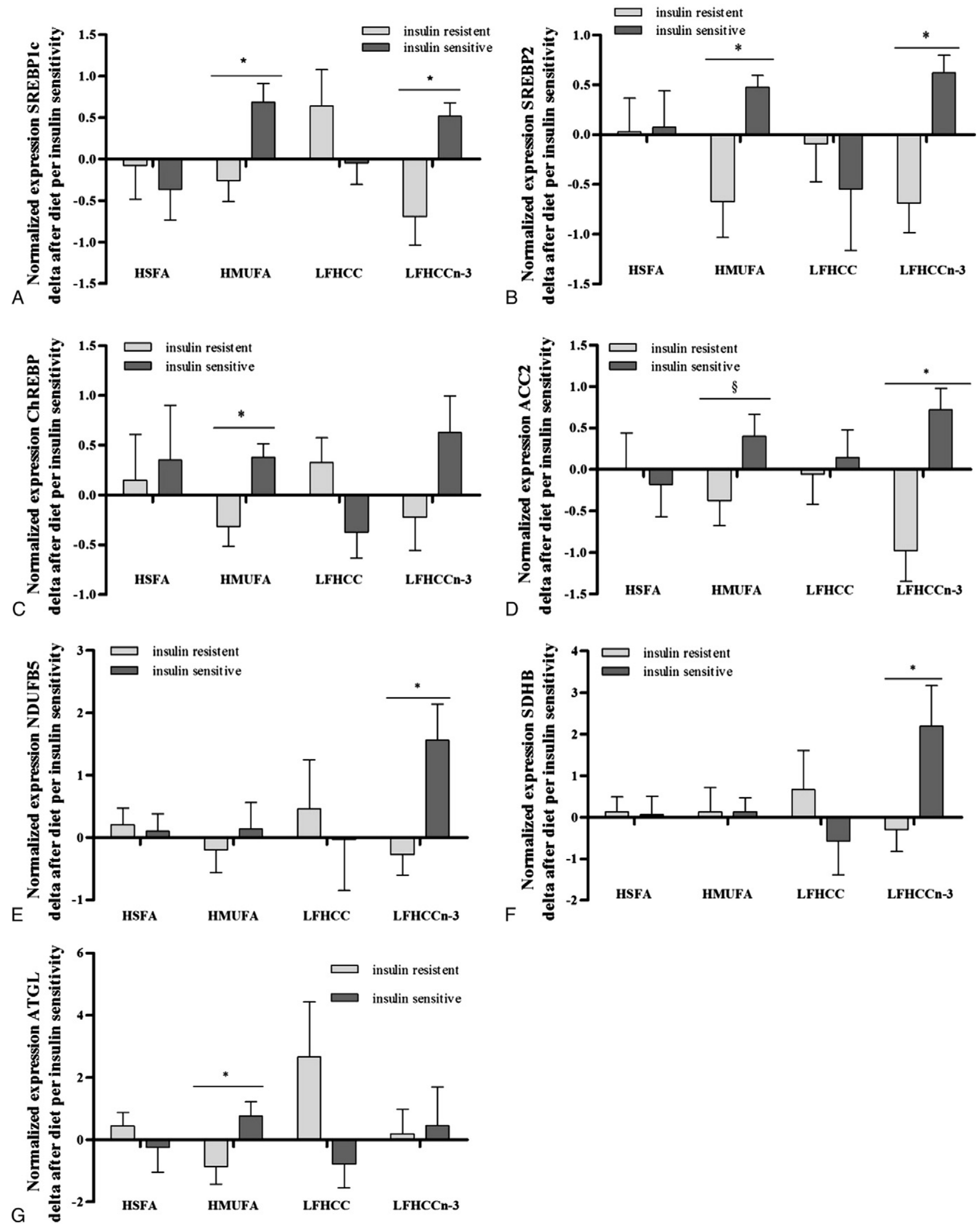
Table 3 - Subject characteristics before and after dietary intervention for the subgroup.

\begin{tabular}{|c|c|c|c|c|c|c|c|c|}
\hline & \multicolumn{2}{|c|}{ HSFA $(n=7)$} & \multicolumn{2}{|c|}{ HMUFA $(n=5)$} & \multicolumn{2}{|c|}{ LFHCC $(n=7)$} & \multicolumn{2}{|c|}{ LFHCCn-3 $(n=7)$} \\
\hline & Pre & Post & Pre & Post & Pre & Post & Pre & Post \\
\hline Age (years) & $59.0 \pm 2.4$ & & $58.6 \pm 5.6$ & & $56.0 \pm 2.2$ & & $56.7 \pm 5.0$ & \\
\hline Height $(\mathrm{m})$ & $1.74 \pm 0.03$ & & $1.74 \pm 0.01$ & & $1.74 \pm 0.02$ & & $1.76 \pm 0.03$ & \\
\hline Body weight $(\mathrm{kg})^{\text {a }}$ & $90.9 \pm 3.1$ & $89.1 \pm 3.6$ & $103.9 \pm 3.0^{\mathrm{b}, \mathrm{c}}$ & $103.9 \pm 2.6$ & $93.7 \pm 3.2$ & $92.8 \pm 3.5$ & $85.7 \pm 4.5$ & $84.2 \pm 5.5$ \\
\hline BMI $\left(\mathrm{kg} / \mathrm{m}^{2}\right)^{\mathrm{a}}$ & $30.2 \pm 1.8$ & $29.2 \pm 2.1$ & $34.2 \pm 0.8^{\mathrm{d}, \mathrm{e}}$ & $34.2 \pm 0.7$ & $30.9 \pm 1.1$ & $30.6 \pm 1.2$ & $27.5 \pm 0.9$ & $26.8 \pm 1.1$ \\
\hline Waist (cm) & $107 \pm 3$ & $103 \pm 3$ & $114 \pm 1$ & $115 \pm 2$ & $107 \pm 2$ & $105 \pm 3$ & $103 \pm 2$ & $100 \pm 3$ \\
\hline WHR & $1.03 \pm 0.01$ & $1.02 \pm 0.02$ & $1.05 \pm 0.02$ & $1.07 \pm 0.02$ & $1.02 \pm 0.01$ & $1.02 \pm 0.02$ & $1.04 \pm 0.02$ & $1.03 \pm 0.02$ \\
\hline Systolic BP (mm Hg) & $136 \pm 8$ & $141 \pm 8$ & $131 \pm 5$ & $132 \pm 7$ & $141 \pm 5$ & $133 \pm 4.5$ & $136 \pm 5$ & $127 \pm 4$ \\
\hline Diastolic BP (mm Hg) & $80 \pm 3$ & $79 \pm 2$ & $85 \pm 4$ & $84 \pm 6$ & $92 \pm 4$ & $87 \pm 4$ & $83 \pm 3$ & $77 \pm 1$ \\
\hline $\begin{array}{l}\text { Insulin sensitivity } \\
\left(\mathrm{mU} / \mathrm{L}^{-1} \cdot \mathrm{min}^{-1} \cdot 10^{-4}\right)\end{array}$ & $2.10 \pm 0.38$ & $3.05 \pm 0.53$ & $2.28 \pm 0.46$ & $2.16 \pm 0.43$ & $1.93 \pm 0.30$ & $1.98 \pm 0.33$ & $2.83 \pm 0.82$ & $3.18 \pm 0.49$ \\
\hline $\mathrm{HOMA}_{\mathrm{IR}}$ & $2.16 \pm 0.56$ & $1.83 \pm 0.68$ & $2.42 \pm 0.65$ & $2.41 \pm 0.42$ & $2.63 \pm 0.33$ & $2.83 \pm 0.82$ & $2.02 \pm 0.27$ & $1.54 \pm 0.20$ \\
\hline Glucose (mmol/L) & $5.69 \pm 0.10$ & $5.66 \pm 0.14$ & $5.71 \pm 0.26$ & $5.78 \pm 0.28$ & $5.83 \pm 0.16$ & $5.74 \pm 0.16$ & $6.01 \pm 0.24$ & $6.09 \pm 0.30$ \\
\hline Triglycerides (mmol/L) & $1.66 \pm 0.27$ & $1.58 \pm 0.24$ & $1.45 \pm 0.42$ & $1.31 \pm 0.27$ & $2.22 \pm 0.50$ & $2.03 \pm 0.45$ & $2.81 \pm 0.73$ & $1.79 \pm 0.16$ \\
\hline $\begin{array}{l}\text { Total cholesterol } \\
(\mathrm{mmol} / \mathrm{L})\end{array}$ & $4.72 \pm 0.44$ & $4.79 \pm 0.34$ & $4.85 \pm 0.29$ & $4.79 \pm 0.32$ & $5.07 \pm 0.40$ & $4.72 \pm 0.42$ & $5.41 \pm 0.18$ & $4.91 \pm 0.22$ \\
\hline HDL-cholesterol (mmol/L) & $0.78 \pm 0.04$ & $0.79 \pm 0.03$ & $0.92 \pm 0.06$ & $1.01 \pm 0.03$ & $0.96 \pm 0.09$ & $0.90 \pm 0.10$ & $0.92 \pm 0.04$ & $0.90 \pm 0.04$ \\
\hline LDL-cholesterol (mmol/L) & $2.74 \pm 0.28$ & $3.26 \pm 0.35$ & $2.94 \pm 0.27$ & $3.02 \pm 0.37$ & $2.87 \pm 0.43$ & $2.87 \pm 0.43$ & $3.56 \pm 0.23$ & $3.17 \pm 0.38$ \\
\hline TAG ( $\mu \mathrm{mol} / \mathrm{g}$ dry weight) & $124.11 \pm 36.9$ & $85.14 \pm 29.94$ & $149.35 \pm 28.97$ & $141.91 \pm 22.59$ & $163.27 \pm 48.63$ & $68.14 \pm 18.44$ & $164.89 \pm 35.32$ & $90.56 \pm 22.26^{f}$ \\
\hline DAG ( $\mu \mathrm{mol} / \mathrm{g}$ dry weight) & $10.27 \pm 3.74$ & $4.85 \pm 1.89$ & $8.02 \pm 0.7$ & $9.14 \pm 3.0$ & $6.57 \pm 1.31$ & $8.25 \pm 1.66$ & $8.11 \pm 1.12$ & $8.68 \pm 1.92$ \\
\hline PL ( $\mu \mathrm{mol} / g$ dry weight) & $77.62 \pm 41.22$ & $74.63 \pm 9.80$ & $61.1 \pm 14.30$ & $79.53 \pm 6.28$ & $64.79 \pm 3.40$ & $73.33 \pm 4.78$ & $70.65 \pm 2.49$ & $83.16 \pm 6.01$ \\
\hline
\end{tabular}

Abbreviations: BMI, body mass index; BP, blood pressure; HDL, high-density lipoprotein; HSFA, high-fat saturated fatty acid; HMUFA, high-fat mono-unsaturated fatty acid; LFHCC, low-fat high complex carbohydrate. Values are mean \pm SEM. No effects of dietary intervention, repeated measures ANOVA.

a $P<.05$ for the differences between groups pre-intervention, one-way ANOVA.

b $P=.025$, post hoc comparison to HSFA.

c $P=.003$, post hoc comparison to LFHCCn-3.

d $\mathrm{P}=, 046$, post hoc comparison to HSFA.

e $P=, 002$, post hoc comparison to LFHCCn-3.

${ }^{f} \mathrm{P}=.032$, post-hoc comparison within LFHCCn-3 diet.

revealed that the HSFA diet trended to increase the ChREBP mRNA expression $(P=.14)$ in men and women. Gene expression of PGC1 $\alpha$, SREBP2, ACC2, MCPT1b, LPL, PPAR $\alpha$, PPARס, NDUFB, SDHB, ATGL, CGI58, HSL, DGAT, CD36, SCD1, NRF, FAS and SIRT1 did not change after dietary intervention (data not shown), and there were no changes in mitochondrial DNA content as result of dietary intervention (data not shown).

The repeated measures ANOVA showed that there was a significant interaction between insulin sensitivity at baseline and diet-induced changes in gene expression for 7 out of 21 genes, which was independent of baseline expression levels. To illustrate these differential effects on gene expression, the total group was divided based on the median of insulin sensitivity $\left(2.69\left(\mathrm{mU} / \mathrm{L}^{-1} \cdot \mathrm{min}^{-1} \cdot 10^{-4}\right)\right.$. At baseline, insulin resistant subjects (below median of insulin sensitivity, age $57.4 \pm 2.95 \mathrm{y}$ and BMI $31.3 \pm 1.0 \mathrm{~kg} /$ $\mathrm{m}^{2}$ ) had higher SREBP1c and ACC2 mRNA expression levels in the fasting state than insulin sensitive subjects (above median of insulin sensitivity $\left(\mathrm{S}_{\mathrm{I}}\right)$, age $56.7 \pm 2.6 \mathrm{y}$ and $\mathrm{BMI}$ $\left.30.5 \pm 1.6 \mathrm{~kg} / \mathrm{m}^{2}\right)(P=.001$ and $P=.020$, respectively, data not shown). Insulin resistant and insulin sensitive subjects responded differently to the HMUFA and the LFHCCn-3 diet in mRNA levels of SREBP1c (diet*time* $\mathrm{S}_{\mathrm{I}}$ interaction $P<.001)$, SREBP2 $(P=.055)$, ChREBP $(P=.040)$, ACC2 $(P=.088)$, NDUFB5 $(P=.071), \quad$ SDHB $(P=.032)$ and ATGL $(P=.029)$ (Fig. 3A, B, C, D, E, F and G, respectively). The HMUFA diet reduced the $m R N A$ level of the lipogenic genes SREBP1c (one-way ANOVA $P=.012$ ), SREBP2 (one-way ANOVA $P=.002$ ), ChREBP (one-way ANOVA $P=.008$ ) and ACC2 (one-way ANOVA $P=.065$ ) and the lipolytic gene ATGL (one-way ANOVA $P=.039$ ) among insulin resistant subjects, whereas the opposite effect was seen in insulin sensitive subjects. Moreover, insulin resistant subjects had lower mRNA levels of SREBP1c (one-way ANOVA $P=.005$ ), SREBP2 (one-way ANOVA $P=.002$ ) and ACC2 (one-way

Fig. 3 - Change in normalized mRNA levels after dietary intervention (mean \pm SEM) among IR and IS subjects as shown for SREBP1C (A), SREBP2 (B), ChREBP (C), ACC2 (D), NDUFB5 (E), SDHB (F) and ATGL (G). The change in gene expression was different between IR and IS subjects after a HMUFA diet for SREBP1c (one-way ANOVA P=.012), SREBP2 (one-way ANOVA P=.002), ChREBP (one-way ANOVA $P=.008$ ), ACC2 (one-way ANOVA $P=.065$ ) and ATGL (one-way ANOVA $P=.039$ ). The change in gene expression was different between IR and IS subjects after a LFHCCn-3 diet for SREBP1c (one-way ANOVA P=.005), SREBP2 (oneway ANOVA $P=.002$ ), ACC2 (one-way ANOVA $P=.002$ ), NDUFB5 (one-way ANOVA $P=.025$ ) and SDHB (one-way ANOVA $P=.049$ ). Significant differences between the change in gene expression differences among IR and IS subjects are indicated with * ${ }^{*} \mathrm{P}<.05$. $\S$ indicates a trend. 
ANOVA $P=.002$ ) after the LFHCCn-3 diet, whereas insulin sensitive subjects showed the opposite effect. The LFHCCn3 diet enhanced expression of the OXPHOS genes NDUFB5 (one-way ANOVA $P=.025$ ) and SDHB (one-way ANOVA $P=.049$ ) among insulin sensitive subjects, but not in insulin resistant subjects.
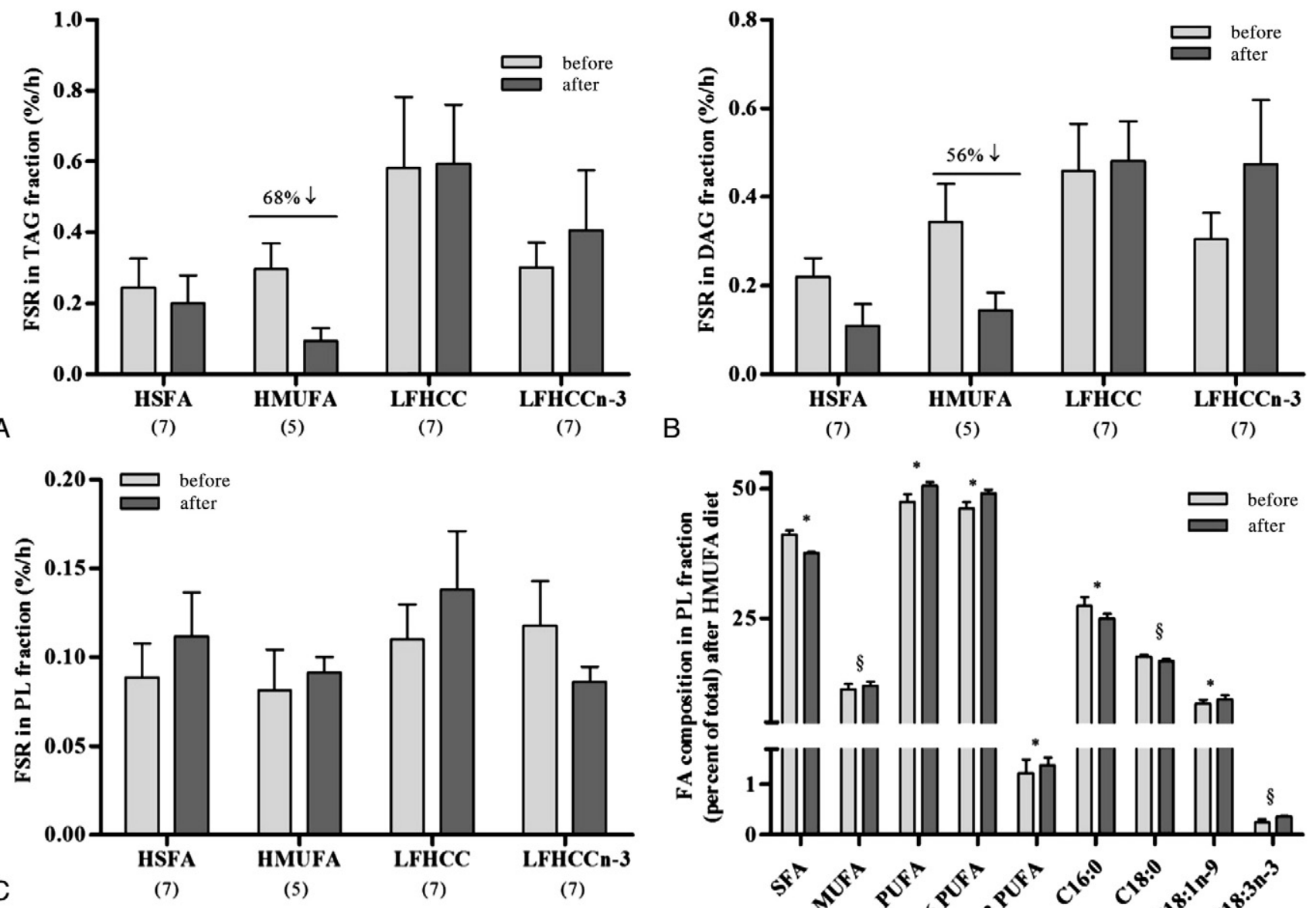

B

(5)

(7)

(7)
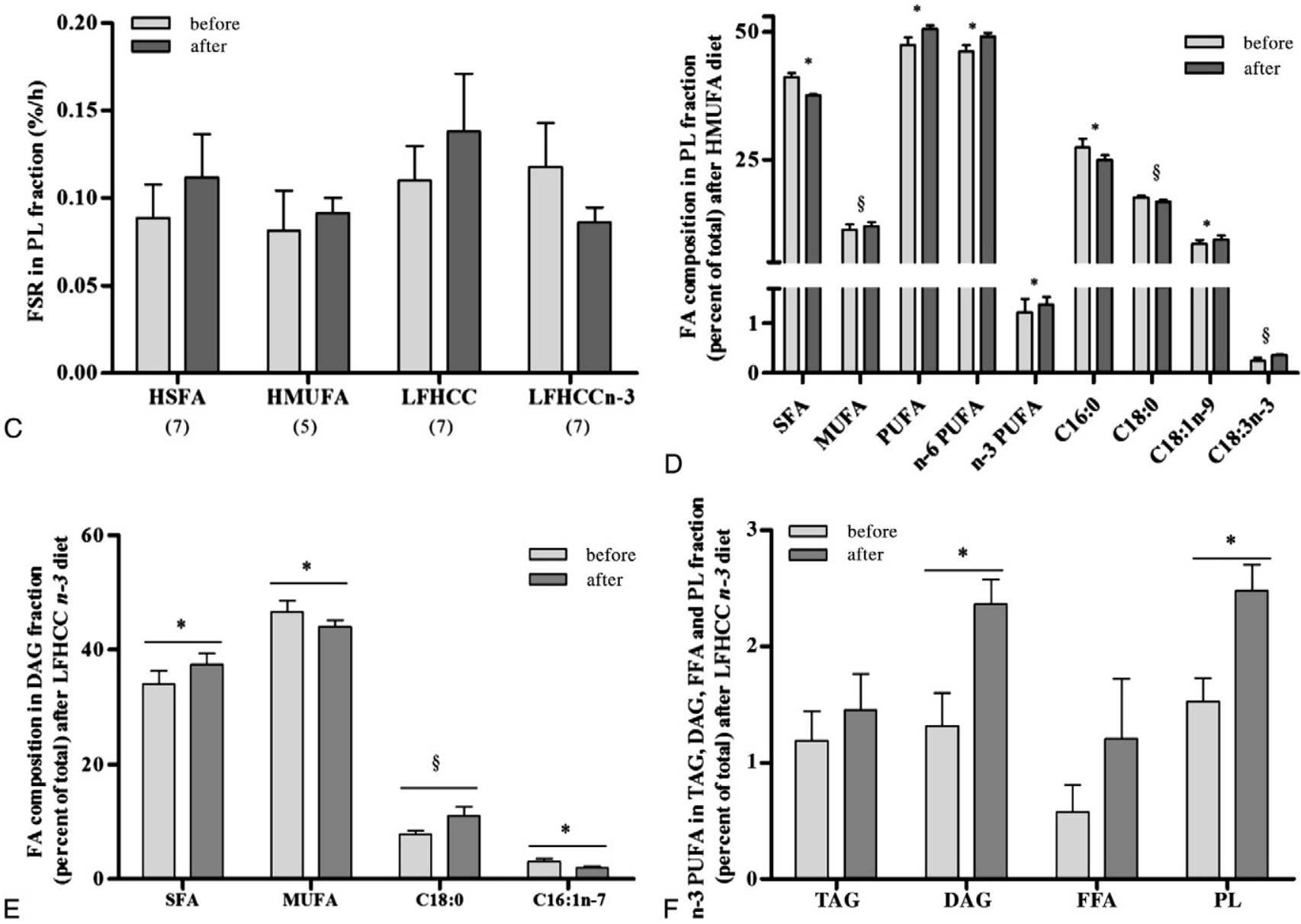

Fig. 4-Incorporation of dietary FA in skeletal muscle as shown for TAG (A), DAG (B) and PL (C) and changes in skeletal muscle FA pattern after dietary intervention as shown for PL after the HMUFA diet (D), change in DAG after the LFHCCn-3 diet (E) and change in $\% n-3$ PUFA after the LFHCCn-3 diet (F). The HMUFA diet seemed to reduce the postprandial FSR of the TAG fraction by $68 \%(P=.054)$ and of the DAG fraction by $56 \%(P=.066)$. The HMUFA diet increased the $\% P U F A(P=.020)$ and the $\%$ MUFA $(P=.071)$. The \% C16:0 ( $P=.024)$ and \% C18:0 (P=.059) were reduced and the \% of C18:1n-9 $(P=.033)$ and $C 18: 3 n-3(P=.082)$ were increased. The LFHCC $n-3$ diet caused enhanced \% SFA $(P=.042)$ and reduced \% MUFA $(P=.023)$ by increasing \% C18:0 (P=.086) and reducing C16:1n-7 $(P=.042)$ in the DAG fraction. The LFHCC $n-3$ diet induced an increase in \% $n-3$ PUFA in the DAG $(P=.007)$ and PL fraction $(P=.036)$. Significant post-hoc differences are indicated with ${ }^{*} .{ }^{*} P<.05$. $\S$ indicates a trend. 


\subsection{Muscle lipid metabolism}

3.2.1. Fractional synthetic rate and content of the TAG, DAG, FFA and PL fractions

A sub-cohort of 26 men at Maastricht University (HSFA, $n=7$; HMUFA, $n=5$; LFHCC, $n=7$ and LFHCC $-3, n=7$ ) completed a postprandial stable isotope study. Subject characteristics were comparable at baseline, except for a slightly higher body weight and BMI among subjects on the HMUFA diet than on the HSFA and LFHCCn-3 diets (Table 3). Total fasting plasma TAG concentration decreased significantly after the LFHCCn-3 diet (Post-hoc testing, $P=.032$, Table 3).

The FSR of the TAG and DAG fraction (the incorporation of $\left[\mathrm{U}-{ }^{13} \mathrm{C}\right]$-palmitate from the high-fat mixed-meal) trended to change as a result of dietary intervention as compared with baseline, but this did not reach statistical significance $(P=.096$ and $P=.126$, RM-ANOVA, Fig. 4). The HMUFA diet seemed to reduce the postprandial FSR of the TAG fraction by $68 \%$ $(P=.054$, Fig. $3 A)$ and of the DAG fraction by $56 \%(P=.066$, Fig. 4B). The four different diets did not induce any changes in FSR in the PL fraction (Fig. 4 C).

\subsubsection{Fatty acid composition of the TAG, DAG, FFA and PL fractions}

The HMUFA diet increased the \% PUFA $(P=.020)$ significantly and trended to increase the \% MUFA $(P=.071)$ in the PL fraction as compared with baseline, concomitant with a reduction in the total degree of FA saturation. Specifically, the \% C16:0 $(P=.024)$ and \% C18:0 $(P=.059)$ were reduced and the \% of C18:1n-9 $(P=.033)$ and C18:3n-3 (P=.082) increased (Fig. 4D). The LFHCC $n-3$ diet caused enhanced \% SFA $(P=.042)$ and reduced $\%$ MUFA $(P=.023)$ by increasing \% C18:0 $(P=.086)$ and reducing C16:1n-7 ( $P=.042)$ in the DAG fraction (Fig. 4E). Furthermore, the LFHCC $n-3$ diet induced an increase in \% n-3 PUFA in the DAG $(P=.007)$ and $P L$ fraction $(P=.036)$ (Fig. $4 \mathrm{~F})$. The HSFA and LFHCC diets did not cause any differences in the FA composition of the different intramuscular lipid fractions.

\section{Discussion}

This study examined the effect of diets differing in fat quantity and quality on skeletal muscle gene expression and intramuscular lipid partitioning in subjects with the MetS. There was a significant interaction between baseline insulin sensitivity and the diet-induced changes in gene expression. The mRNA expression of the lipogenic genes SREBP1C and ACC2 decreased in insulin resistant subjects after the HMUFA and the LFHCCn-3 diets whilst the LFHCCn-3 diet enhanced OXPHOS (NDUFB5 and SDHB) mRNA expression among insulin sensitive subjects. The HMUFA diet also decreased the ATGL mRNA in insulin resistant subjects. In line with this, the HMUFA diet tended to reduce incorporation of dietary palmitate in skeletal muscle TAG and DAG, whereas the LFHCCn-3 diet reduced the TAG content in skeletal muscle. There were no dietary effects on the expression of genes important for mitochondrial function, biogenesis and transport, FA transport and lipolysis.

The HMUFA diet increased SREBP1c mRNA expression in men, but not in women. Interestingly, in the total cohort of the
LIPGENE dietary intervention study, it was shown that increases in insulin sensitivity $\left(\mathrm{HOMA}_{\mathrm{IR}}\right)$ were more pronounced in women compared with men on the HMUFA diet [24]. Based on the gene expression data, it is tempting to speculate that this sexual dimorphism may be related to differences in skeletal muscle fat storage. This seems consistent with findings of an increased rate of FA oxidation during a high MUFA diet in women compared with men [32].

The insulin resistant and insulin sensitive subjects responded differently to the HMUFA and LFHCCn-3 diets with a more pronounced reduction of SREBP1C and ACC2 mRNA expression among insulin resistant subjects and an enhanced expression of the OXPHOS genes NDUFB5 and SDHB on the LFHCCn-3 diet among insulin sensitive subjects. Although baseline expression levels of SREBP1C and ACC2 were higher in the insulin resistant group, the reduction of these lipogenic genes was independent of the baseline difference. In aggregate with the larger reduction of the lipogenic genes, the HMUFA diet seemed to reduce the incorporation of dietary FA (palmitate) in the DAG and TAG pool and the LFHCCn-3 diet reduced the skeletal muscle TAG content in the subgroup of men. These data indicate a shift towards a lower accumulation of lipids in muscle on the diets high in MUFA or high in complex carbohydrates with $n-3$ supplement, which is dependent on the initial degree of insulin sensitivity (or insulin resistance). The primary mechanism for PUFA or MUFA to regulate SREBP1c mRNA may be related to the suppression of proteolytic processing, which in turn reduces mRNA transcription [33]. Low SREBP1c and ACC2 mRNA levels may lead to reduced malonyl-CoA concentration (via a reduction in ACC2 mRNA expression), and subsequently FAs are directed towards oxidation instead of storage [34].

Previous studies have shown that diet may influence the FA composition of PL, which may influence the action of insulin within the skeletal muscle [8,9]. A high level of PUFA in PL also may enhance membrane fluidity [8], the number of insulin receptors [12], the affinity of insulin to the insulin receptor [13] and glucose transport across the membrane [14]. In our present study we found a reduced saturation of the skeletal muscle PL fraction after an HMUFA diet (increased content oleic acid) and enhanced incorporation of $n-3$ PUFA in the DAG and PL pools on the LFHCCn-3 diet, illustrating dietary compliance to our intervention diets. Thus, it seems that the supplemented n-3 PUFAs are incorporated into the DAG and PL fractions, in accordance with that the FA composition of skeletal muscle reflects the dietary fat composition in humans [35]. In a previous study, however, differences in the TAG fraction were also shown, whereas we only observed changes in the DAG and PL fractions. Increased $n-3$ in these fractions can contribute to a lower saturation level of these fractions.

A possible limitation of our sub-study on skeletal muscle fat metabolism is the relative small number of subjects per group for the more detailed stable isotope measurements on fatty acid handling. To eliminate the between center differences the stable isotope study was performed in one center. In the muscle gene expression study, center was included as a random variable in the statistical analysis. The effect of HMUFA and LFHCCn-3 on lipogenic gene expression and on PL FA composition might be beneficial for insulin sensitivity in the long-term. Our present sub-study was not intended and 
powered to study the effect on insulin sensitivity. However, also in the whole LIPGENE study no differential effects of diets on insulin sensitivity were found [24]. It is possible that the 12week dietary period is too short or the changes in dietary composition and subsequent changes in skeletal muscle FA metabolism were too small to translate into significant differences in insulin sensitivity. It is also possible that $n-6$ PUFA, rather than MUFA or $n-3$ PUFA enhances insulin sensitivity in subjects with the MetS [36].

In summary, the 12-week HMUFA and LFHCCn-3 diets induced changes in gene expression and skeletal muscle FA partitioning, which may shift the balance from storage to oxidation in insulin resistant subjects, leading to less muscle lipid accumulation. Furthermore, these two diets affected skeletal muscle PL composition with less SFA on the HMUFA diet and an enhanced level of $n-3$ PUFA on the LFHCCn-3 diet. These positive effects on lipid metabolism did not promote changes in insulin sensitivity. This might suggest that the range of dietary fat intake under condition of isoenergetic exchange was insufficient to affect insulin sensitivity or that lipid metabolism per se has no prominent role in the regulation of insulin sensitivity.

\section{Author Contributions}

AJ: conducted the data analysis with advice and input from $\mathrm{AH}, \mathrm{LS}$ and $\mathrm{EB}$; UR, $\mathrm{CD}, \mathrm{HR}$, and $\mathrm{EB}$ (principal investigators): study design and obtainment of funding; AJ, AH, IG, LS and AT: data collection. All authors critically reviewed and edited the final article.

\section{Funding}

Supported by a grant from the Dutch Diabetes research Foundation and this work was part of the LIPGENE project, an EU Sixth Framework Integrated Program funded by the European Community (Contract no. FOOD-CT-2003-505944), in addition to The Johan Throne Holst Foundation and Freia Medical Foundation.

\section{Acknowledgments}

We thank the participants for so enthusiastically taking part in the present study. We are grateful to all of the staff at different centers whose help ensured the smooth running of this study.

\section{Conflict of interest}

None of the authors had a financial or personal conflict of interest to report.

\section{R E F E R E N C E S}

[1] Eckel RH, Grundy SM, Zimmet PZ. The metabolic syndrome. Lancet 2005;365:1415-28.

[2] Corpeleijn E, Saris WH, Blaak EE. Metabolic flexibility in the development of insulin resistance and type 2 diabetes: effects of lifestyle. Obes Rev 2009;10:178-93.
[3] Schrauwen P. High-fat diet, muscular lipotoxicity and insulin resistance. Proc Nutr Soc 2007;66:33-41.

[4] Itani SI, Ruderman NB, Schmieder F, Boden G. Lipid-induced insulin resistance in human muscle is associated with changes in diacylglycerol, protein kinase C, and IkappaBalpha. Diabetes 2002;51:2005-11.

[5] Schrauwen P, Hesselink MK. Oxidative capacity, lipotoxicity, and mitochondrial damage in type 2 diabetes. Diabetes 2004;53:1412-7.

[6] Corcoran MP, Lamon-Fava S, Fielding RA. Skeletal muscle lipid deposition and insulin resistance: effect of dietary fatty acids and exercise. Am J Clin Nutr 2007;85:662-77.

[7] Bruce CR, Thrush AB, Mertz VA, Bezaire V, Chabowski A, et al. Endurance training in obese humans improves glucose tolerance and mitochondrial fatty acid oxidation and alters muscle lipid content. Am J Physiol Endocrinol Metab 2006;291:E99-107.

[8] Borkman M, Storlien LH, Pan DA, Jenkins AB, Chisholm DJ, et al. The relation between insulin sensitivity and the fattyacid composition of skeletal-muscle phospholipids. N Engl J Med 1993;328:238-44.

[9] Helge JW, Dela F. Effect of training on muscle triacylglycerol and structural lipids: a relation to insulin sensitivity? Diabetes 2003;52:1881-7.

[10] Pan DA, Lillioja S, Milner MR, Kriketos AD, Baur LA, et al. Skeletal muscle membrane lipid composition is related to adiposity and insulin action. J Clin Invest 1995;96:2802-8.

[11] Storlien LH, Jenkins AB, Chisholm DJ, Pascoe WS, Khouri S, et al. Influence of dietary fat composition on development of insulin resistance in rats. Relationship to muscle triglyceride and omega-3 fatty acids in muscle phospholipid. Diabetes 1991;40:280-9.

[12] Ginsberg BH, Jabour J, Spector AA. Effect of alterations in membrane lipid unsaturation on the properties of the insulin receptor of Ehrlich ascites cells. Biochim Biophys Acta 1982;690:157-64.

[13] Grunfeld C, Baird KL, Kahn CR. Maintenance of 3T3-L1 cells in culture media containing saturated fatty acids decreases insulin binding and insulin action. Biochem Biophys Res Commun 1981;103:219-26.

[14] Field CJ, Ryan EA, Thomson AB, Clandinin MT. Diet fat composition alters membrane phospholipid composition, insulin binding, and glucose metabolism in adipocytes from control and diabetic animals. J Biol Chem 1990;265:11143-50.

[15] van Hees AM, Saris WH, Hul GB, Schaper NC, Timmerman BE, et al. Effects of dietary fat modification on skeletal muscle fatty acid handling in the metabolic syndrome. Int J Obes (Lond) 2010;34:859-70.

[16] Madsen L, Petersen RK, Kristiansen K. Regulation of adipocyte differentiation and function by polyunsaturated fatty acids. Biochim Biophys Acta 2005;1740:266-86.

[17] Gaster M, Rustan AC, Beck-Nielsen H. Differential utilization of saturated palmitate and unsaturated oleate: evidence from cultured myotubes. Diabetes 2005;54:648-56.

[18] Lee JS, Pinnamaneni SK, Eo SJ, Cho IH, Pyo JH, et al. Saturated, but not $n-6$ polyunsaturated, fatty acids induce insulin resistance: role of intramuscular accumulation of lipid metabolites. J Appl Physiol 2006;100:1467-74.

[19] Roberts R, Bickerton AS, Fielding BA, Blaak EE, Wagenmakers AJ, et al. Reduced oxidation of dietary fat after a short term high-carbohydrate diet. Am J Clin Nutr 2008;87:824-31.

[20] Roche HM. Fatty acids and the metabolic syndrome. Proc Nutr Soc 2005;64:23-9.

[21] Hannah VC, Ou J, Luong A, Goldstein JL, Brown MS. Unsaturated fatty acids down-regulate srebp isoforms $1 \mathrm{a}$ and $1 \mathrm{c}$ by two mechanisms in HEK-293 cells. J Biol Chem 2001;276:4365-72.

[22] Patti ME, Kahn BB. Nutrient sensor links obesity with diabetes risk. Nat Med 2004;10:1049-50.

[23] Shaw DI, Tierney AC, McCarthy S, Upritchard J, Vermunt S, et al. LIPGENE food-exchange model for alteration of dietary 
fat quantity and quality in free-living participants from eight European countries. Br J Nutr 2009;101:750-9.

[24] Tierney AC, McMonagle J, Shaw DI, Gulseth HL, Helal O, et al. Effect of dietary fat modification on insulin sensitivity and other risk factors of the metabolic syndrome-LIPGENE: an European randomized dietary intervention study. Int $J$ Obes (Lond) 2011;35:800-9.

[25] Cohen P, Miyazaki M, Socci ND, Hagge-Greenberg A, Liedtke $\mathrm{W}$, et al. Role for stearoyl-CoA desaturase-1 in leptinmediated weight loss. Science 2002;297:240-3.

[26] Finegood DT, Hramiak IM, Dupre J. A modified protocol for estimation of insulin sensitivity with the minimal model of glucose kinetics in patients with insulin-dependent diabetes. J Clin Endocrinol Metab 1990;70:1538-49.

[27] Boston RC, Stefanovski D, Moate PJ, Sumner AE, Watanabe RM, et al. MINMOD Millennium: a computer program to calculate glucose effectiveness and insulin sensitivity from the frequently sampled intravenous glucose tolerance test. Diabetes Technol Ther 2003;5:1003-15.

[28] Bergstrom J, Hermansen L, Hultman E, Saltin B. Diet, muscle glycogen and physical performance. Acta Physiol Scand 1967;71:140-50.

[29] Bustin SA. Absolute quantification of mRNA using real-time reverse transcription polymerase chain reaction assays. J Mol Endocrinol 2000;25:169-93.
[30] Bogacka I, Xie H, Bray GA, Smith SR. Pioglitazone induces mitochondrial biogenesis in human subcutaneous adipose tissue in vivo. Diabetes 2005;54:1392-9.

[31] Matthews DR, Hosker JP, Rudenski AS, Naylor BA, Treacher $\mathrm{DF}$, et al. Homeostasis model assessment: insulin resistance and beta-cell function from fasting plasma glucose and insulin concentrations in man. Diabetologia 1985;28:412-9.

[32] Kien CL, Bunn JY. Gender alters the effects of palmitate and oleate on fat oxidation and energy expenditure. Obesity (Silver Spring) 2008;16:29-33.

[33] Takeuchi Y, Yahagi N, Izumida Y, Nishi M, Kubota M, et al. Polyunsaturated fatty acids selectively suppress sterol regulatory element-binding protein-1 through proteolytic processing and autoloop regulatory circuit. J Biol Chem 2010;285:11681-91.

[34] Pender C, Trentadue AR, Pories WJ, Dohm GL, Houmard JA, et al. Expression of genes regulating malonyl-CoA in human skeletal muscle. J Cell Biochem 2006;99:860-7.

[35] Andersson A, Nalsen C, Tengblad S, Vessby B. Fatty acid composition of skeletal muscle reflects dietary fat composition in humans. Am J Clin Nutr 2002;76:1222-9.

[36] Summers LK, Fielding BA, Bradshaw HA, Ilic V, Beysen C, et al. Substituting dietary saturated fat with polyunsaturated fat changes abdominal fat distribution and improves insulin sensitivity. Diabetologia 2002;45:369-77. 